\title{
"Burkini" Bans in Belgian Municipal Swimming Pools: Banning as a Default Option
}

\author{
Eva Brems, Saïla Ouald Chaib and Katrijn Vanhees ${ }^{1}$
}

\section{INTRODUCTION}

In the summer of 2016, so-called "burkini" bans on French beaches drew worldwide attention. In its neighbouring country Belgium, politicians and media eagerly joined the debate, confirming once more the saying 'when it pours in Paris, it rains in Brussels'. France's "burkini" beach bans were eventually ruled illegal, and Belgium never introduced them. Yet in the meantime, under the radar in Belgium, body covering swimwear is banned in the majority of municipal swimming pools, which are the prime swimming spots in the country. The lack of attention for these bans in municipal swimming pools is surprising, especially since their potential impact on women who wish to swim with a "burkini" is even more important than bans applying to the beach. In fact, these bans in swimming pools deny access to basic sport activities throughout the entire year. This research zooms in on such bans in Flanders, the Northern Dutch-language region of Belgium. In Section 2 it maps the prevalence and stated reasons behind Flemish "burkini" bans in municipal swimming pools, Section 3 looks into the experiences of "burkini" wearers, before analysing the bans in the light of European human rights standards in Section 4. First however, a short introduction is due to the "burkini" debate, which is discussed in Section 1.1 and the Belgian context regarding restrictions on female Muslims' dress is discussed in Section 1.2.

\section{1. 'When it POURS in Paris...': The “burkinI” debate IN the SUMmer of 2016 in France}

The word "burkini" is an unfortunate description. The combination of "burqa" and "bikini" is only witty if one can shake off the negative connotations of the idea of a burqa. Since the introduction of the socalled "burqa bans" in France and Belgium - in 2010 and 2011 respectively - ${ }^{2}$ that is not an option. Yet what sounds like an Islamophobic slur in Europe, was conceived as simply an eye-catching brand name in the very different context of Australia. In a country with a strong beach culture, the designer was targeting a previously unaddressed segment of the market: Muslim women who want to respect religious modesty requirements, while fully participating in Australia's beach culture. ${ }^{3}$ Despite being a brand name and registered trademark, burqini/burkini became the generic term to indicate body covering swimwear worn by Muslim women, as is available from numerous brands today. ${ }^{4}$ It is made out of similar fabric as other swimwear. It covers the entire body, but leaves the face, the hands and the feet uncovered. ${ }^{5}$ It consists of two separate pieces; the pants and a tunic worn over the pants. Additionally, the swimsuit also comes with a cap or hood, sometimes attached to the swimsuit, which in many cases covers the neck as well.

\footnotetext{
${ }^{1}$ Eva Brems is a professor of Human Rights Law at the Human Rights Centre at Ghent University, Saïla Ouald Chaib is a postdoctoral researcher, and Katrijn Vanhees a PhD researcher at the same Centre.

2 France: Act $n^{\circ}$ 2010-1192 of 11 October 2010 prohibiting the concealment of the face in public; Belgium: Act of 1 June 2011 to institute a prohibition on wearing clothing that covers the face, or a large part of it, BS 13 July 2011.

3 <Ahiida.com>; accessed 22 August 2018; Helen McCue and Ghena Krayem, 'Shari'a and Muslim Women's Agency in a Multicultural Context: Recent Changes in Sports Culture' in A. Possamai and others (eds.), The Sociology of Shari'a: Case Studies from around the World (Springer 2015) 112.

${ }^{4}$ The authors prefer the use of the term 'body covering swimwear'. For the purpose of this article, however, they will use the term "burkini" for practical reasons.

${ }^{5}$ Some models have shorter sleeves and pants.
} 
It was at the end of July 2016 - with the beach season at Côte d'Azur in full swing- that the mayor of Cannes launched the new trend of banning "burkinis" from the municipal beaches. ${ }^{6}$ Cannes was followed by around 30 other municipalities, out of a total of 923 coastal municipalities in France. ${ }^{7}$ This happened against the background of the terrorist attack in Nice on 14 July 2016 that killed 86 people. Civil society organisations Ligue des Droits de l'Homme (LDH) and Collectif Contre l'Islamophobie en France (CCIF) challenged the municipal bans in summary proceedings in court. The Administrative court of Nice rejected the first complaint (against the municipality of Cannes) on the ground of a lack of urgency. ${ }^{8}$ It rejected the second complaint (against the municipality of Villeneuve-Loubet) on substantive grounds, stating that 'beaches are not appropriate places to express in an ostentatious manner one's religious convictions', and that 'following the succession of Islamist attacks in France, the wearing of the burkini causes risks of disturbing public order'. ${ }^{9}$ The latter ruling was appealed before the Council of State, which ruled in summary proceedings on 26 August 2016 to suspend the municipality's decision. It ruled that such a ban would be within the power of the mayor only if there was evidence of risks of disturbance of public order. It stated that 'in the absence of such risks, the emotion and concerns resulting from the terrorist attacks, and notably the one committed in Nice on 14 July, cannot suffice to legally justify the contested ban'. ${ }^{10}$ This was confirmed in a second ruling regarding the municipality of Cagnes-sur-Mer, where a verbal dispute had taken place between "burkini" wearers and other beachgoers. Yet in the eyes of the Council of State, this was not sufficiently serious to count as a risk for public order. ${ }^{11}$ These rulings seem to have settled the matter. One mayor who introduced an explicit "burkini" ban in the summer of 2017 on the beach of a new leisure park, withdrew the ban even before a court could rule on it. ${ }^{12}$

\section{2. '... IT RAINS IN BRUSSELS': "BURQA" BANS AS VARIATIONS ON A FAMILIAR THEME}

The "burkini" bans of course echo other types of restrictions on Muslim women's religious dress that have been adopted in France (and Belgium) since the 1990s. Most notably these include headscarf bans - formulated as bans on religious symbols - for pupils and teachers in public schools, and in the workplace for public servants as well as increasingly in the private sector. In addition, there is the nationwide ban on face covering in public, widely known as the 'burqa ban'. It is clear that from several perspectives, this is part of the same pattern. Some commentators have moreover pointed out the important post-colonial context in France, given the historical weight of the veil and the process/phenomenon of unveiling, in French-Algerian colonial history. ${ }^{13}$ Indeed, the "burkini" is, like the hijab and the niqab, another manifestation of "the veil', which 'in the Western orientalising

\footnotetext{
${ }^{6}$ Concretely, these decisions did not mention the "burkini" as such, but rather banned swimwear that did not respect the principle of laïcité (the French conception of secularism), for example municipalities of Cannes and Villeneuve-Loubet, as cited by Council of State, cf. infra.

7 Nicolas Hervieu, 'Burkini: Entretien croisé des Professeurs Stéphanie Hennette-Vauchez et Joël Andriantsimbazovina sur la décision du Conseil d'Etat - Liberté de religion et ordre public' La Revue des droits de l'homme, Actualités Droits-Libertés, [2016], 1, 12.

${ }^{8}$ TA Nice, Ord. Ref. 13 August 2016 req. $n^{\circ}$ 1603470, cited Hervieu, (n 7) 2.

${ }^{9}$ TA Nice, Ord. Ref. 22 August 2016 req. $n^{\circ s} 1603508$ and 1603523, cited in Hervieu (n 7) 2, translation EB.

${ }^{10} \mathrm{CE}$, Ord. Ref. 26 August 2016 req. $\mathrm{n}^{\circ}$ 402742, para. 6, translation EB. For case comments, see Philipe Cossalter, 'The French burkini case: "Uncover this breast I cannot behold", 5 September 2016 and Carine Goberville, 'C'est l'été: coquillages et burkini - Protection de l'ordre public ou nouvelle définition de l'ordre social?', 20 October 2018 both on <www.revuegeneraledudroit.eu/blog> accessed 22 August 2018; Stéphanie Wattier, 'Le Conseil d'Etat français suspend l'interdiction du port du "burkini",'(2017) Revue trimestrielle des droits de l'homme, 110, 407-419.

${ }^{11}$ CE, Ord. Ref. 26 September 2016 req. $n^{\circ} 403578$.

12 This was a ban on 'monokinis, burkinis, and veils that cover the face completely or in part, or combinations' translation EB (CE, Ord. Ref. 26 July 2017 req. $n^{\circ}$ 412636).

${ }^{13}$ Linda Berg and Mikela Lundahl, 'Un/veiling the West - Burkini-gate, Princess Hijab and Dressing as Struggle for Postsecular Integration' (2016) 8(3) Culture Unbound 263, 267-268.
} 
imagination... is seen as... a symbol of otherness, oppression, backwardness and in need of development' ${ }^{14}$ In addition, in the post 9/11 world, the veil worn by a minority of women in Europe increasingly signifies in the eyes of Christian and secular majorities not just Islam, but also radical Islam, extremist Islam, and dangerous Islam. ${ }^{15}$

The common undercurrent in initiatives to ban different types of veiling is revealed in the commonality of the political discourse promoting such bans. When asked to give a legal justification, public as well as private actors can be seen to revert to similar lines of argument with regard to all these different situations. Recurring themes are neutrality/secularism and gender equality/women's rights. As the analysis in Section 4 shows, the latter argument does not stand in the light of ECtHR case law, and the former can apply to some specific contexts, but not to private individuals in the general public sphere, as is the case for face covering bans, and "burkini" bans. Yet what is most remarkable about the "burkini" bans, at least in France, is that the conclusion of the legal debate is that the bans cannot be justified. While the main legal argument concerns the powers of the mayor, the Council of State has ruled that the ban 'is a serious and manifestly illegal violation of fundamental freedoms, to know the freedom of movement, the freedom of conscience and personal freedom' ${ }^{16}$ Hijab bans and face covering bans on the other hand, have been cleared by domestic as well as supranational courts. ${ }^{17}$

The context in which Flemish municipalities adopted their bans, is one in which bans on "veiling" spread like an oil spill across many sectors of society. In addition to the nationwide face covering ban, "religious signs" are banned in the majority of schools, as well as by an increasing number of employers, both in the public and private sector, and some judges ban them in the courtroom. ${ }^{18}$ Another problematic development has been the refusal of access to services to women wearing a hijab. When such refusals are challenged in court, the applicant may win her case, but she may also lose it. A Belgian Appeal Court has held that the refusal to admit a woman as a client in a fitness centre on account of her headscarf was not discriminatory, ${ }^{19}$ and a Court of First Instance has held that the refusal to admit two women as clients in an ice cream parlour on account of their headscarves was not

\footnotetext{
14 ibid 265.

${ }^{15}$ Cf. Cindy Jung, 'Criminalization of the burkini' (2016) 7 Harvard International Review: 'calling the swimsuit "the uniform of extremist Islamism"... commits the fatal error of equating radical Islam to Islam itself'.

${ }^{16}$ CE, Ord. Ref. 26 August 2016, nr 402742, (n 10), para 6, translation EB. Although the rulings of the French Council of State concern 'burkini bans' in a beach context, the same principles can also be invoked in a swimming pool context. However, as the analysis below will show, in the swimming pool context, a number of justifications (notably hygiene and safety) are invoked, that do not feature in the debate in the beach context.

${ }^{17}$ A Grand Chamber of the European Court of Human Rights cleared the face covering ban: S.A.S. v France App no 43835/11 (ECtHR, 1 July 2014); the Court of Justice of the European Union accepted bans on 'religious signs' in the private sector when based on a neutrality policy: Case C-157/15 Samira Achbita and Centrum voor gelijkheid van kansen en voor racismebestrijding v G4S Secure Solutions NV, originating in Belgium [2016] ECLI:EU:C:2016:382; Case C-188/15 Asma Bougnaoui and Association de Défense des Droits de l'Homme $v$ Micropole Univers SA [2016] ECLI:EU:C:2016:553 which originated in France.

18 See Eva Brems, Corina Heri, Saïla Ouald Chaib, and Lieselot Verdonck, 'Head-covering Bans in Belgian Courtrooms and Beyond: Headscarf Persecution and the Complicity of Supranational Courts' (2017) 39(4) Human Rights Quarterly 882.

${ }^{19}$ Brussels 8 September 2015, nr 2014/AR/2354, Interfederale Centrum voor Gelijkheid van Kansen en voor Racismebestrijding v NV S, www.unia.be.available at

< https://www.unia.be/files/Z_ARCHIEF/2015_09_08_brussel.pdf> accessed 22 August 2018. The Court of Appeal accepted a ban on all types of headgear as necessary on grounds of safety, despite several proposals by the applicant for less far-reaching measures.
} 
discriminatory. ${ }^{20}$ Even though a Court of Appeal overruled the ice cream parlour case, ${ }^{21}$ and even though courts also found discrimination in the cases of a woman who was refused access to the summer terrace of a bar ${ }^{22}$ and of a woman who was refused access as a client in a bowling alley, ${ }^{23}$ the overall outcome is one of legal uncertainty, in which headscarf bans are potentially justifiable in virtually any context. To veil wearers, this communicates a status of "outlaws", whereas to potential veil banners, it communicates impunity and even encouragement. In such a context, the widespread existence of bans on body-covering swimwear under the radar of politicians, scholars and activists, should not come as a big surprise. When confronted with a manifestation of Islamic veiling, banning seems to be the default option in Belgian society.

\section{DRESS RESTRICTIONS IN FLEMISH MUNICIPAL SWIMMING POOLS}

This Section presents our findings regarding the prevalence of "burkini" bans in Flemish municipal swimming pools, and the reasons that are invoked to justify such bans.

\subsection{A Methodological Note}

First, the swimming pool rules of all municipal swimming pools in Flanders were collected. This included all swimming pools that are managed either by the municipality or a collective of municipalities (intercommunale) or by public-private cooperation. In most cases these were separate rules applicable only to one or more swimming pools. In some cases, the provisions on the swimming pool were part of a rule on municipal sport infrastructure in general. The large majority of these pools are indoor pools. In most cases, these rules were available online. In each rule, we identified the provisions containing dress rules applicable to the general public when using the pool.

Next, we contacted $131^{24}$ swimming pools by telephone, using the number that is provided on the pool's website. In the conversation, we identified ourselves as academic researchers, and we asked for more information on the interpretation and practical application of the dress rules. We obtained responses from 129 swimming pools. ${ }^{25}$ The persons answering our calls had different statuses: some were staffing the pool's entry booth, others were employed in a desk job in the municipal sports department. Some consulted with a superior before replying to some questions, others gave their own opinion, or the facts 'as far as they knew'. In some cases, the interviewee indicated that she/he was not a 100 percent certain of her/his answer. Yet also in cases where the interviewee spoke in an assertive tone, there may be a degree of subjectivity or incompleteness in some answers. However, the persons we called, are the same persons that would be called by a customer contacting the pool

\footnotetext{
${ }^{20}$ Court of First Instance of West Flanders (sec. Veurne) 2 July 2014, AR nr. 14/043/C, Interfederale Centrum voor Gelijkheid van Kansen en voor Racismebestrijding/Dick G.) available at <https://www.unia.be/files/Z_ARCHIEF/2014_07_02_rb_veurne.pdf>. The ban was an application of an internal rule of the ice cream parlour that banned all headgear.

${ }^{21}$ Ghent, 8 October 2015, nr 2014/AR/2354 Interfederale Centrum voor Gelijkheid van Kansen en voor Racismebestrijding/Dick G available at www.unia.be.< https://www.unia.be/nl/rechtspraakalternatieven/rechtspraak/hof-van-beroep-gent-8-oktober-2015> accessed 22 August 2018.

${ }^{22}$ Court of First Instance Brussels 22 December 2009, Procureur du Roi/X, RG 2009/12.031/A, available at <https://www.unia.be/files/Z_ARCHIEF/RG200912031A.PDF> accessed 22 August 2018.

${ }^{23}$ Court of First Instance Brussels 25 January 2011, L. and Centrum voor Gelijkheid van Kansen en voor Racismebestrijding/NV V, available at www.unia.be

< https://www.unia.be/files/Z_ARCHIEF/2011_01_25\%20Vz\%20\%20Rb\%20\%20Brussel.pdf> accessed 22 August 2018.

${ }^{24}$ These are all the Flemish municipal swimming pools except those that we knew to be temporarily closed at the time of the research. The telephone round took place between January and July 2017.

${ }^{25}$ Of the remaining 16 swimming pools, some were also closed, and in the other cases, no representative was available for an interview.
} 
to enquire after the applicable dress rules. While the results of the telephone survey may therefore diverge somewhat from actual practice, they give a fairly accurate picture from the perspective of such customers.

\section{2. "BURKINI" BANS IN THE CONTEXT OF POOL DRESS CODES}

Dress restrictions are a frequent feature of swimming pool rules. We found only four cases in which the swimming pool rules did not include any dress restrictions. In three of these cases, the telephone interview revealed that dress restrictions were nevertheless applied in practice.

We found 21 cases in which the rules explicitly ban the burkini, that is to say, rules that mention the word "burkini" as such. In addition, 46 pool rules contain an implicit ban on body covering swimwear. In most cases this means that the rules stipulate the types of swimwear that are allowed (often separated by gender), mentioning (for men) swim shorts, and (for women) 'a bathing suit or a bikini'. Two rules implicitly allow body covering swimwear. ${ }^{26}$ Finally, 61 pools have unclear rules on this point. These are rules that leave a lot of room for interpretation, such as stipulations that swimwear should be 'decent' or 'appropriate' or that it should not 'give offense'. In addition, the requirement that swimwear should be 'tight' leaves room for interpretation when applied to the "burkini". Some pools display visuals at the entrance that indicate what swimwear is and is not allowed. We found several cases in which the visual specifically shows a "burkini "among the swimwear that is not allowed.

On the telephone, we learned that body-covering swimwear is or would be allowed in 24 municipal pools. This number includes 9 cases in which the issue was theoretical in the sense that to the knowledge of the interviewee, no one had ever wanted to swim with body-covering swimwear in that pool. For 15 pools, it was clear that at least one woman has been able to swim in practice with bodycovering swimwear. These include the two pools with rules that implicitly allow such swimwear, and 13 pools with rules that are unclear on this point. In 5 pools, it was not clear whether any woman had already swum with body-covering swimwear.

The telephone round revealed that in 70 pools, body-covering swimwear is or would be banned. This number includes 21 pools that have never received a request to wear such swimwear. Of these 21 'theoretical banners', 4 have explicit bans in the rules, 7 have implicit bans, and 9 have unclear rules on this point and one has no rules. For 47 pools, the interviewee indicated that the issue of bodycovering swimwear had arisen in practice at least once, meaning that in (at least) these 47 pools, at least one person has been refused access on this ground. These include 10 pools that have an explicit ban in their rules, 25 that have an implicit ban, and 12 with rules that are unclear on this point. In 9 pools in which the "burkini" was either banned or its status was unclear, we found that it was nevertheless allowed either during school swimming (3 cases) and/or during specific 'women's swimming hours' targeting minority women, which were often organised by a club renting the pool (7 cases).

At the same time, it is to be noted that dress rules that specifically target male swimwear are also very widely applied. Here also, we found that in addition to those pools that stipulate restrictions in their rules, some other pools also apply similar restrictions without an unambiguous basis in the rules. Among the swimming pools we examined, no less than 104 require swim shorts to be short, that is not longer than the knees. In addition, a total of 79 pools require swim shorts to be tight (often referred to as the 'speedo-model'). 34 pools combine both requirements.

\subsection{INVOKED REASONS FOR DRESS RULES IN SWIMMING POOLS}

\subsubsection{In general}

\footnotetext{
${ }^{26}$ Both rules mention that swimwear has to be made of 'swimwear material'. One of the rules adds that it must conform to morals.
} 
To the extent that the swimming pool rules themselves refer to reasons underlying dress restrictions, these are overwhelmingly of three types: hygiene, safety and morals/decency. ${ }^{27}$

Hygiene is mentioned specifically as a reason for dress restrictions in 37 rules. This concern is reflected in specific requirements concerning 'hygienic swimwear' (12), 'clean swimwear' (18), and bans on wearing underwear in the pool (36). In addition, the concern for hygiene is reflected in bans on types of dress that can also be worn outside the pool: cycling shorts (6), shirts (9), headwear that is not a swim cap (14), jeans (9), dresses (16), trousers (14), leggings (4), skirts (19), shoes (1), T-shirts (34) and leisurewear (14). Another related rule is the ban on pockets in swimwear, which occurred 20 times.

From the explanations given during the telephone round, it became clear that staff in many pools are weary of people coming to the pool wearing the same shorts they wear outside the pool. They argue that such shorts are often dirty, including in particular the content of the pockets which may include dirt, wrappers, tissues etc. Concrete stories about people coming to the pool straight from football practice or from playing in the park, wearing the same trousers, and about filters full of grass or tissues result in a persuasive account of hygiene as a motivation behind some of the restrictions.

Somewhat related to the concern for hygiene, is the issue of ecology (related to water quality) which is mentioned in 12 rules. In this same context, 19 rules require swimwear to be made of lycra or swimwear material'.

Safety is mentioned 23 times as a ground for dress restrictions. This includes requirements of 'safe swimwear' (11), 'loose swimwear' (12), zippers (10), swimwear that restricts swimmers' movement (1), as well as some of the bans on specific (loose) dress items mentioned above.

References to decency or morals appear to have in mind swimwear that is not sufficiently covering. Only one rule explicitly forbids nude swimming, yet this is implicitly banned in other rules. We found bans of monokini (topless swimwear) (9), strings (13), transparent swimwear (1), and requirements of 'decent' swimwear (42). 9 rules stipulate that swimwear should not 'give offense'; a reference which may be applied also to swimwear that is perceived as overly covering.

\subsubsection{As applied to "burkinis"}

During the telephone round, in those cases where the "burkini" is not allowed, we asked interviewees why this was the case. 50 interviewees replied to that question. Hygiene was by far the most cited reason with 36 mentions, in addition to 3 mentions of ecology/water quality and 2 interviewees stating that it is difficult to distinguish from ordinary clothing which is banned. Apart from 2 interviewees who believed that underwear was worn under a "burkini", we did not collect much explanation on the argument from hygiene. Given the broader context in which a ban on swimwear that is 'too long' is generally justified by reference to hygiene, this argument may not be surprising. However, upon closer examination, the parallel with the restrictions on swim shorts does not hold, as it cannot be credibly argued that the "burkini" is worn outside the pool. ${ }^{28}$

Safety was mentioned by 13 interviewees. Among those who explained this, some referred to the risk of loose clothes that may get stuck in filters and others to a 'parachute effect' that would hinder other swimmers. Such lines of reasoning may however to some extent be based on misperceptions on the looseness of a "burkini".

Finally, 7 interviewees referred to reasons that could be grouped as 'majority morals'. To be clear, this is an interpretation of morals that requires uncovering rather than covering. Three interviewees stated that the "burkini" was 'offensive', and one interviewee each mentioned neutrality, integration, tradition, and gender equality.

\subsection{Contextual elements}

\footnotetext{
${ }^{27}$ In many cases, several reasons were invoked.

${ }^{28}$ This argument was indeed not made in the interviews.
} 
The interviews revealed that requests by Muslim women to wear body-covering swimwear, do not necessarily concern the "burkini" as such. Wetsuits are sometimes worn as an alternative, and a small number of swimming pools recommend these to clients who want to wear covering swimwear. Some girls also wear shorts over bathing suits. In addition, some women ask to wear items that are not swimwear as such, in the sense that they are made of different material, including leggings or T-shirts. Such requests are generally refused. However, this context may explain some of the answers of interviewees, in the sense that some concerns of hygiene and safety may apply to such non-burkinitype covering swimwear.

The broader societal context of islamophobia and intolerance vis-à-vis Islamic dress, occasionally transpired in the interviews. Three interviewees volunteered their opinion that 'those who come here have to adapt to our rules'. And one interviewee mentioned 'the ethical question of what to do with women who are forced to wear a burkini'. Six interviewees used the term "burka", and in one instance this term was even used in the swimming pool rules. Three interviewees mentioned "veiled" swimming. In addition to such expressions of the attitudes of the interviewees, the interviews also revealed two instances of incidents in which other swimmers had protested against the wearing of a "burkini" when it was allowed. In one case, when the incident was during general public swimming hours, the pool staff assessed this as 'inspired by racism' and dismissed it. In the other case, a participant in "aqua zumba" classes objected to other participants wearing "burkinis", because "as a train conductor, she was confronted with burkas all day at work ${ }^{29}$, and did not want to see this in the pool'. According to the interviewee, 'this problem solved itself', as the women wearing "burkinis" stopped attending the class.

\section{Perspectives of "Burkini" Wearers Challenging Bans}

The 2016 "burkini debate" in France, led to a debate in Belgian media and politics as well. The rightwing government party N-VA ${ }^{30}$ stated that they favoured a "burkini" ban on Belgian beaches as well as in swimming pools. ${ }^{31}$ They received some support as well as some negative reactions from opinion makers. A group of Muslim women organised a "burkini beach party"32 in the city of Antwerp to protest the proposed ban, as well as the discourse of the mayor of Antwerp (also the N-VA president), who had called "burkini" wearers "tent wearers". After the ruling of the French Conseil d'État, the debate quickly died out, and the proposal for a ban was never introduced in Parliament. To many observers, the conclusion seemed to be that this time, France had gone too far, and was not an example to be followed. In this debate, the fact that some swimming pools ban "burkinis" was occasionally mentioned, but the scale of these bans was never revealed, and the debate focused mostly on the beach.

In July 2017, UNIA, Belgium's inter-federal equality body, issued an 'advice on body-covering swimwear', in which it concluded that bans on such swimwear are not compatible with anti-

\footnotetext{
${ }^{29}$ Given the criminal ban on face covering in public in Belgium, this statement should not be taken at face value. Most likely, the use of the term 'burka' in this context refers to other types of Islamic dress.

${ }^{30} \mathrm{~N}-\mathrm{VA}$ stands for 'Nieuw Vlaamse Alliantie' (New Flemish Alliance). This is a party with a conservative and Flemish-nationalist agenda, with a strong emphasis on a tough stance on immigration. This is the biggest party in both the federal and Flemish coalition governments.

${ }^{31}$ Belga/RR, 'N-VA wil algemeen verbod op boerkini's in zwembaden en aan stranden' (Knack, 17 August 2016) $\leq$ www.knack.be/nieuws/wereld/n-va-wil-algemeen-verbod-op-boerkini-s-in-zwembaden-en-aanstranden/article-normal-741011.html > accessed 22 August 2018.

${ }^{32}$ See photos on http://www.dewereldmorgen.be/foto-reportage/2016/08/27/fotos-strandfeest-in-antwerpenvrouw-en-vrij. See photos on Frederik Sadone, 'Foto's: Strandfeest in Antwerpen, vrouw én vrij' (De wereld morgen.be, 27 August 2017) <www.dewereldmorgen.be/foto-reportage/2016/08/27/fotos-strandfeest-inantwerpen-vrouw-en-vrij> accessed 22 August 2018.
} 
discrimination law. ${ }^{33}$ With this advice at hand, UNIA engaged in dialogue with municipal authorities about the possibility of withdrawing their "burkini" bans. In the meantime, the mobilisation around this topic encouraged some women who had for many years been attempting to swim with a "burkini" in municipal pools, to challenge municipal bans in court. ${ }^{34}$ In September 2017, they introduced three civil suits under anti-discrimination legislation on account of not being allowed to swim with a bodycovering swimsuit in municipal pools. Kareema and Samira sued the city of Antwerp after being refused permission to swim in a "burkini" in a municipal swimming pool in February of the same year. ${ }^{35}$ Samira in addition sued the city of Ghent, where she had been confronted with a similar situation in June 2017. Catherine sued the municipality of Merelbeke on account of being thrown out of the municipal swimming pool in December 2016 for wearing a "burkini". All three are higher educated women around the age of 30 at the time of the facts. ${ }^{36}$ Kareema and Samira were raised in Muslim families with a migration background, Catherine converted to Islam as a young adult. We interviewed Samira and Kareema together in October 2017 in Antwerp and Catherine in December 2017 in Ghent. ${ }^{37}$

THE "BURKINI" CHOICE

Before the incidents that lead to the court cases, all three women had been refused permission to swim with a "burkini" on several occasions in different pools. All three had previously undertaken some kind of action to protest such "burkini" bans. Catherine had approached the ombudsperson of the City of Ghent as well as the alderman responsible for Sports in 2012. ${ }^{38}$ Samira had issued a complaint with the Belgian Equality body ${ }^{39}$ regarding a swimming pool in Antwerp in 2015. And Kareema had coorganised the "burkini beach party" in Antwerp in August 2016.

These women had been swimming with a "burkini" for the last 6 to 10 years. Catherine found her first "burkini" when purposefully searching for modest swimwear online. Kareema was alerted by the media of the start of Ahiida and bought hers from that brand online. And Samira found her first "burkini" in Tunisia, during a beach holiday. Before that time, Samira and Kareema had been 'improvising' when going to the beach. Samira would wear long 'surfer' trousers and a 'surfer' top with long sleeves. Kareema would wear 'anything that is long and dark, not transparent', not necessarily in nylon or lycra. These stories testify to the recent appearance of the "burkini", as well as to the fact that it responded to a real need for these women. They want to combine a religious lifestyle with an active lifestyle, including sportive swimming and beach holidays.

For all three women, the choice of modest swimwear is an automatic consequence of their choice of wearing an Islamic headscarf.

\footnotetext{
${ }^{33}$ Interfederal Centre for Equal Opportunities (UNIA), 'Advies Lichaamsbedekkende Zwemkledij', Advies 166 (10 July 2017), available on www.unia.be<ttps://www.unia.be/files/...advies/Advies_lichaamsbedekkende_zwemkledij2.pdf> accessed 22 August 2018.

${ }^{34}$ The applicants in these cases are assisted by the Legal Clinic of the Human Rights Centre of Ghent University. The present authors are involved in the supervision of these files.

${ }^{35}$ The Court of First Instance East Flanders (sec. Ghent). The Ghent court of first instance ruled on 5 July 2018 that the bans in Ghent and Merelbeke are discriminatory. The Antwerp case is still pending.

${ }^{36}$ Catherine is a medical doctor, Samira is a teacher, and Kareema is a student. Catherine, Samira, and Kareema are pseudonyms.

37 The interviews took place in Dutch and were transcribed in Dutch. Dutch is the mother tongue of the interviewees as well as the interviewers. Translations in English are done by the authors, with minimal linguistic corrections.

${ }^{38}$ This was reported in the media: Marieke Van Pee, 'Heeft klacht ingediend bij ombudsvrouw.

Gentse moslima wil zwemmen in burkini' Nieuwsblad (8 June 2012)

$<$ https://www.nieuwsblad.be/cnt/dmf20120607_00175983.> accessed 22 August 2018.

${ }^{39}$ The complaint was raised with the Interfederal Centre for Equal Opportunities (UNIA: ): <www.unia.be. $\geq$ accessed 22 August 2018.
} 
so you decide to wear a headscarf out of an Islamic conviction. And you decide not only to cover your head but a much bigger surface of your body.... So for me it is an extension of the same thing. ... I do not consider a burkini as a religious item, but I need it to continue my religious practice. ${ }^{40}$

A central part of this religious lifestyle is the matter of 'agency about your own body and deciding yourself which part to show'. ${ }^{41}$

It is simply about what you consider private and what can be visible for all eyes and yes you see, you feel it then as not appropriate or wrong if you do have to show your body in a way that you do not feel comfortable with. ${ }^{42}$

Catherine points out that there are additional benefits to the wearing of a "burkini":

I did notice that for a number of other reasons it is also very comfortable and practical. First of all because I am a bit heavier and then I do not have to be embarrassed about eh cellulitis or you know fat rolls that people look at when you go swimming.... but also for example if I swim outdoors, I am a person who gets sunburnt very easily, and I like to snorkel for example... It is wonderful to not have to worry about that for example.

\section{Stories of rejection and exclusion}

These women love swimming and used to swim frequently in municipal pools as children, which they stopped doing when they started wearing a headscarf and dressing modestly. Currently, on account of the "burkini" bans in the municipalities where they live, swimming has become a rare thing in their lives, reserved for holidays abroad and occasional day trips to a rare pool that allows "burkinis". Occasionally Kareema or Samira may rent a private pool with female friends, yet they complain that such pools are quite expensive and are too small for actual swimming, being generally part of a sauna complex. All three state that they would love to go swimming every week, or even more frequently, 'instead of going to the gym', ${ }^{43}$ as a preferred sport for medical reasons, ${ }^{44}$ and as a family activity ${ }^{45}$. They applaud the concept of "ladies' hours" in the pool, but they do not see it is a good option for themselves, referring to the time schedules which are not suitable for working women, as well as to the fact that they want to swim with the persons of their choice, who may be male. ${ }^{46}$

All three have developed a practice of inquiring in advance whether a swimming pool will allow their swimwear. As a result, most of the rejections they encountered took place by e-mail or telephone. They found that these rejections are often not accompanied by reasons, with the interlocutor simply referring to another person or authority. In the incidents that led Samira and Catherine to submit complaints (see above), they explicitly asked for the reasons behind the bans. Remarkably, in both instances the first reason offered was 'neutrality'.

\footnotetext{
${ }^{40}$ Quote from Samira.

${ }^{41}$ Quote from Kareema.

42 Quote from Catherine.

${ }^{43}$ Quote from Kareema.

${ }^{44}$ Samira refers to asthma and a bad knee; Catherine refers to problems with her back and joints.

${ }^{45}$ Kareema and Catherine would like to go swimming with their children; Samira would like to go swimming with her husband and with her father, like they used to do when she was a child; her father is now old and still swims a lot, 'it is good for his back'.

${ }^{46}$ Between the lines there may also be another issue at stake; reference was made in the conversation with Kareema and Samira to the fact that these women's hours have been introduced to activate house wives of the first generation of immigrants, a category with which they do not identify.
} 
And then I received an e-mail, ... from the swimming pool of Borgerhout, that the swimming pool is neutral, and that there is no place for religion in the water. And that they refer me to the ... women's hour. Which is funny actually. So they seem to consider the women's hour as the Islamic hour .... ${ }^{47}$

And then he said (the alderman of the city of Ghent in an e-mail, EB) ... it has to do with neutrality. At that point my head completely exploded, like what does this have to with neutrality. You could just as well put a sign in the library that people who do not look neutral do not have access. ${ }^{48}$

The above quote from Catherine is representative of many of the feelings expressed by the interviewees about the bans, and for their analyses of what is going on. For them, this is not only about swimming. It is not only about losing freedom of choice in the matter of swimwear. They see this as part of a much a broader pattern that they are very keenly aware of.

Samira's analysis is that:

there is a hierarchy in society. There are people who can enjoy all rights. And there are others who have to be subservient. Namely "you have to adapt because our rights have priority". Because that is how it is really. Whether we are offended, or our human rights are violated, does not matter, as long as the white man is not offended in the swimming pool.;

In her eyes, the "burkini" ban confirms Muslim women's status as 'second rank citizens'.

Kareema agrees that it is about 'superiority and inferiority', yet also describes how her first reaction was not combative at all:

I think I mainly felt very alone in that matter.... Because many women do not go to the pool and are not confronted with this rejection, so I somehow felt very alone in this. And also, I think in part I had internalised that they make the rules, so it is not allowed. Until it became a lot bigger for me personally .... Last summer with the "burkini" ban on the beach in France.

For Catherine, it is a matter of 'sheer arbitrariness' and of 'a majority that can decide how a minority should dress and behave'. She also sees this as part of a broader picture:

I think the ban is purely about identity and fear of the average Belgian to be confronted with the changing of society and that what they consider normal might actually be changed. I think this conservatism is still present in the Belgian like 'we think that our society should really be typically Flemish with typically Flemish habits' and I think that many people have difficulties with increasing diversity and that the burkini or women with a headscarf more generally have somehow become the symbol of that.

\section{WEARER'S PROFILES}

In the "burkini summer" of 2016, a prominent Belgian lawyer commented on the "burkini debate" in a manner that pretended to know the women who claim the right to wear modest swimwear, and more generally any kind of "veil":

\footnotetext{
${ }^{47}$ Quote from Samira.

${ }^{48}$ Quote from Catherine.
} 
the wearing of such signs often seems like... an act of provocation, an act of rejection, an act of defiance. It is about contesting the foundational principles of our democratic states and militating for another type of societal organization, based on shari'a. ${ }^{49}$

The fact that this opinion was published in a mainstream legal journal testifies to the fact that his view is widely shared in Belgian society. The conversation with some of the most activist "burkini" wearers in the country, allows to assess such statements as baseless. There may be people in Belgian society who reject democratic values in the name of shari'a, but this is far from the profile of "burkini" wearers. The interviewees confirm that 'really orthodox Muslims, or those who follow the stricter schools' ${ }^{50}$ are unlikely to ever wear a "burkini", as they consider swimming inappropriate on account of the presence of other swimmers' undressed bodies.

This [wearing a "burkini" - EB] is actually often about women like I said who are somewhat more open-minded, often somewhat higher educated and who mainly actually will decide themselves what they consider the essence of their belief, and what they consider true and what they consider not true. It is not about people who blindly follow certain religious leaders, but about people who really have their own idea about how they want to experience their religion and they actually try to integrate all aspects of their lives as well as possible. So, they want to participate actively in society; they are usually people who work, who are also active in the community, and who also want to participate in sports activities, and who then actually go looking for clothes to actually integrate their religious conviction with their active lifestyle: how they want to stand in life and actively participate really in society. And actually, that is the dramatic thing that you then really exclude that group. ${ }^{51}$

\section{DROWNING HUMAN RIGHTS?}

In the Belgian court cases, "burkini" bans are challenged under domestic anti-discrimination law. In the two cases in which a judgment was issued, the court found discrimination on ground of religion. ${ }^{52}$ At the point of writing, it is not yet clear whether the case will move to the appeal level, yet this seems likely.

As Belgium has a monist legal system (meaning that it recognises the direct effect of international human rights law in domestic law), the European Convention on Human Rights (ECHR) played an important role in the parties' argumentations, and also appears in the Belgian court's reasoning. Should the bans in the final instance be cleared by the Belgian courts, the last word on the matter will be for the European Court of Human Rights, that can hold the Belgian state accountable for any human rights violations committed by public authorities, including municipalities, as well as for any human rights violations condoned by its courts. This section will therefore analyse the Flemish municipal "burkini" bans in the light of the case law of the European Court of Human Rights (ECtHR or the Court). The "burkini" has so far made a single appearance in the Court's case law. The applicants in Osmanoğlu and Kocabaş $v$ Switzerland ${ }^{53}$ claimed a religious exemption from compulsory mixed swimming classes

\footnotetext{
${ }^{49}$ Patrick Henry, 'Au Nom de Qui? Ou de Quoi ?' [2016] (30) Jurisprudence de Liège, Mons et Bruxelles 1400, 1401; translation from French EB.

${ }^{50}$ Quote from Catherine.

${ }^{51}$ Quote from Catherine.

${ }^{52}$ Court of first instance East Flanders (sec. Ghent) 5 July 2018, YA/city of Ghent a.o. ('Ghent case') available at <https://www.unia.be/files/Documenten/Rechtspraak/Rechtbank_van_eerste_aanleg_Gent_5_juli_2018_(zw embad_Van_Eyck).pdf> accessed 22 August 2018, and Court of first instance East Flanders (sec. Ghent) 5 July 2018, SH/city of Merelbeke a.o. ('Merelbeke case'), para 4.9 available at < https://www.unia.be/files/Documenten/Rechtspraak/Rechtbank_van_eerste_aanleg_Gent_5_juli_2018_(zwe mbad_Merelbeke).pdf> accessed 22 August 2018.

${ }^{53}$ Osmanoğlu and Kocabaş v Switzerland App no 29086/12 (ECtHR, 10 January 2017).
} 
in primary school for their daughters. The ECtHR did not find a violation in this case. In its assessment of the proportionality of the ban, it attaches some weight to the fact that 'the authorities have offered significant accommodations to the applicants', ${ }^{54}$ including the fact that their daughters had the possibility to wear 'a burkini' in swimming class. The applicants protested that wearing a "burkini" would have a stigmatising effect on their daughters. In the eyes of the Court however, there was no evidence for such stigmatising effect. ${ }^{55}$ With regard to the Court's approach to "burkini" bans, not much guidance can be derived from this judgment, except than for the fact that the Court does not regard the "burkini" as such as a priori problematic ${ }^{56}$. In addition, it may be relevant that the Court emphasises in particular the value of swimming together with others (as opposed to an alternative of private swimming classes). ${ }^{57}$

As the "burkini" is worn to comply with religious prescripts, there can be no doubt that it falls within the scope of article 9 ECHR, which protects the right to freedom of thought, conscience and religion. Under this provision, any interference with the freedom of religion ought to be prescribed by law (legality requirement), needs to pursue a legitimate aim and must be necessary in a democratic society. ${ }^{58}$ In some municipalities, the bans are based on interpretations of vague provisions, that may be considered to be unforeseeable for the rights holders. As such, these bans may fail under the legality requirement of article 9, paragraph 2 ECHR. For most bans however, the relevant legal question will be whether they can be considered as "necessary in a democratic society" for the pursuit of a "legitimate aim". The case law that domestic courts are most likely to consult for guidance, is that regarding bans on Islamic headscarves and face veils. The Court has examined bans of religious dress/symbols for teachers ${ }^{59}$ and pupils ${ }^{60}$ in schools, for photographs on identity documents ${ }^{61}$, and in public sector employment ${ }^{62}$, and it has examined face covering bans that apply in the entire public sphere $^{63}$. In all these cases, it has found that the state had acted within its wide margin of appreciation in this field. The measures were considered justifiable in light of the state's objective of neutrality, or the protection of others against pressure on their conscience, or - in the face veil cases - the goal of "living together". In what follows, the relevance of these same objectives for the "burkini" bans will first be explored in Section 4.1., then some other possible justifications that are specific to the swimming pool context will be examined in Section 4.2.

\subsection{BANNING THE “BURKINI” FOR SIMILAR REASONS AS OTHER MUSLIM WOMEN'S DRESS?}

\subsubsection{NeUtrality in the POOL?}

\footnotetext{
54 ibid, para 101 (translation from French EB).

55 ibid, para 101.

${ }^{56}$ This is relevant, in light of the fact that for a long time, the Court considered the Islamic headscarf as inherently problematic, stating that it appeared to be imposed on women by a religious precept that was hard to reconcile with the principle of gender equality. It also noted that wearing the Islamic headscarf could not easily be reconciled with the message of tolerance, respect for others and, above all, equality and non-discrimination' (Leyla Şahin v Turkey App no 44774/98 (ECtHR, 10 November 2005) para 111).

57 Osmanoğlu and Kocabaş v Switzerland (n 53), paras 98 and 100.

${ }^{58}$ Article 9, para 2 ECHR.

${ }^{59}$ Dahlab v Switzerland App no 42393/98 (ECtHR, 15 January 2001); Kurtulmus v Turkey App no 65500/01 (ECtHR, 24 January 2006); Karaduman v Turkey App no 41296/04 (ECtHR, 3 April 2007); Tandoğan v Turkey App no 41298/04 (ECtHR, 3 April 2007); Çağlayan v Turkey App no 30461/02 (ECtHR,21 October 2008); and Yilmaz v Turkey App no 15380/09 (ECtHR, 12 February 2013).

${ }^{60}$ Leyla Şahin v Turkey (n 57); Kervanci v France App no 31645/04 (ECtHR, 8 December 2008) and Dogru v France App no 27058/05 (ECtHR, 4 December 2008); Aktas v France App no 43563/08 (ECtHR, 30 June 2009); Bayrak v France App no 14308/08 (ECtHR, 17 July 2009) Gamaleddyn v France App no 18527/08 (ECtHR, 17 July 2018); Ghazal v France App no 29134/08 (ECtHR, 30 June 2009).

${ }^{61}$ Mann Singh v France App no 4479/07 (ECtHR, 13 November 2008).

${ }^{62}$ Ebrahimian v France App no 64846/11 (ECtHR, 26 November 2015).

${ }^{63}$ S.A.S. v France (n 17); Belcacemi and Oussar v Belgium App no 37798/13 (ECtHR, 11 July 2017); Dakir v

Belgium App no 4619/12 (ECtHR, 11 July 2017).
} 
The argument that a ban on religious dress is needed in the interest of the protection of government neutrality or secularism was accepted by the Court in the context of bans on religious dress/symbols worn by students and professors in public educational institutions, as well as by public servants in general. Neutrality was a prominent argument that was advanced in the French "burkini" debate, with mayors stating that the beach is not a proper place to manifest one's religion (see above). In the Flemish context, this view has been applied to the swimming pool. Both Catherine and Samira met the neutrality argument (see above). When Catherine's case was examined by the ombudsperson of the city of Ghent, the latter found that the alderman responsible for sports in the city government had motivated the "burkini" ban by stating that this was 'a political choice in favour of religious neutrality in public swimming pools' ${ }^{64}$ The ombudsperson ruled that Catherine's complaint was justified, in that the neutrality argument cannot justify such a ban. ${ }^{65}$

Indeed, while neutrality may be a relevant argument regarding the appearance of public facilities as such (for example, a crucifix on the wall), it would be a far stretch to extend it to the appearance of the users of public facilities. Their "public" character means that they should be open to all. Or in the words of our interviewees: 'they are paid for with our tax money'. ${ }^{66}$ In a recent case, concerning a ban on religious headgear for a witness in a criminal court, the ECtHR distinguished private citizens from public officials: while the latter 'may be put under a duty of discretion, neutrality and impartiality, including a duty not to wear such symbols and clothing while exercising official authority', '(i)n democratic societies, private citizens... are normally not under such a duty'. ${ }^{67}$ Hence it seems unlikely that the ECtHR would accept neutrality as a justification for a "burkini" ban. Likewise, the Court of first instance of Ghent rejected the argument of neutrality, stating that it is the role of public authorities to promote tolerance among different groups of the population. ${ }^{68}$

\subsubsection{PRESSURE ON OTHER SWIMMERS?}

Another rationale that has regularly been accepted by the Court is that of protecting-supposedly vulnerable-individuals against pressure that would threaten their freedom of conscience. This argument was upheld in the context of alleged pressure upon Turkish university students to wear a headscarf. ${ }^{69}$ A variant was used also concerning a teacher in a Swiss primary school who wore a headscarf. ${ }^{70}$ Applied to the swimming pool, the idea would be that the wearing of body covering swimwear by some swimmers would put pressure on other swimmers to cover themselves. While peer pressure in fashion is a widely accepted phenomenon, the assumption is that it can be problematic in some contexts, when it translates into pressure to have a more religious lifestyle than the individual would freely choose to adopt. As we found in our research, the current situation in municipal swimming pools in Flanders - even those that allow body-covering swimwear - is one in which "burkini"-clad swimmers are rare. In the current context, it would seem that the existence of such pressure cannot be substantiated. In this regard it is relevant to point out that individuals who might want to promote a strict version of an Islamic lifestyle, are likely to adhere to a view that rejects swimming in public altogether. Yet in case a context in which pressure is exercised on female Muslim swimmers to cover their bodies is identified in the future, an intervention to reduce that pressure is

\footnotetext{
64 Ombudsperson of the city of Ghent, Annual Report (2012) $222<$ https://stad.gent/sites/default/files/page/documents/Jaarverslag_Ombudsvrouw\%202012_boek\%202.pdf> accessed 22 August 2018.

65 Ibid. 223.

${ }^{66}$ Quote from Kareema and from Catherine.

${ }^{67}$ Hamidović v Bosnia and Herzegovina App no 57792/15 (ECtHR, 5 December 2017), para 40.

68 'Ghent case' (n 52), para 4.7.

69 Leyla Şahin v Turkey (n 57).

${ }^{70}$ Dahlab v Switzerland (n 58).
} 
justified, and arguably even needed from a human rights perspective. In line with the case law of the Belgian Council of State regarding headscarf bans in public schools, ${ }^{71}$ it would seem that such an intervention can take the form of a ban, but only when less restrictive measures, such as measures targeting only the specific individuals who cause the problem, are not adequate. However, it would be wrong to assume or anticipate such pressure; actual evidence of its existence is needed in order to justify a ban. ${ }^{72}$ Hence, in the Belgian context, it does not seem that an argument based on pressure on other swimmers can justify the existing "burkini" bans.

\subsubsection{SWIMMING TOGETHER, LIVING TOGETHER?}

Several interviewees in our telephone round stated that body covering swimwear was banned because it was considered to be 'offensive' (see above). Similarly, UNIA found that some swimming pool officials referred to (potential) negative reactions of other swimming pool users as a justification for the ban. It replied to this argument that discriminatory motives cannot justify discrimination. ${ }^{73}$ However, some swimming pool users may object to body covering swimwear worn by others for reasons that are not as such discriminatory. In a case that was treated by the Dutch Equality Body in 2009, the argument was that a ban was necessary to prevent uncomfortable feelings from arising among swimmers on account of the difference between those who are more and less (un-)dressed. The Equality Body found discrimination, arguing that the aim may be legitimate, yet there are many other means available to create a good atmosphere in the pool, and the ban was a disproportionate measure. ${ }^{74}$ UNIA furthermore rejected a variation of this argument, that refers to 'swimming culture' as a justification for the ban. It states that swimming cannot be narrowed to a recreational matter within a swimming culture; it is a very low-threshold sport with positive health effects, as well as a life-saving skill that should be mastered by all for safety reasons. ${ }^{75}$

In the face veil cases, the ECtHR accepted far reaching bans on face covering in the entire public sphere, on the ground of an argument of 'living together'. The Court stated that:

It can understand the view that individuals who are present in places open to all may not wish to see practices or attitudes developing there which would fundamentally call into question the possibility of open interpersonal relationships, which, by virtue of an established consensus, forms an indispensable element of community life within the society in question. The Court is therefore able to accept that the barrier raised against others by a veil concealing the face is perceived by the respondent State as breaching the right of others to live in a space of socialisation which makes living together easier. ${ }^{76}$

In principle, the concept of "living together", which ultimately justifies face covering bans on account of the fact that they make many people uncomfortable, could be extended to a wide range of contexts, including bans on body covering swimwear. However, the ECtHR focuses its argumentation in the face veil cases very specifically on the fact that they concern the covering of the face, and on the importance of the face in human interaction. A similar reasoning cannot be credibly developed with regard to the

\footnotetext{
${ }^{71}$ Council of State ( $9^{\text {th }}$ r.) 14 October 2014, X and five others/het Gemeenschapsonderwijs, nr. 228.748.

72 ibid.

73 UNIA (n 33) 9.

${ }^{74}$ CGB 13 March 2009, Oordeelnummer 2009-15, in the case of (Stichting Artikel 1 Overijssel/College van Burgemeester en Wethouders van de gemeente Hengelo).

${ }^{75}$ UNIA (n 33) 9-10. Reference is made to Ester Wisse and Agnes Elling, 'Watervrees, mannenvrees en burquinivrees', W.J.H. Mulier Instituut.

${ }^{76}$ SAS v France (n 17), para 122.
} 
importance of uncovered thighs and arms in the swimming pool context. As a result, it does not appear possible to justify "burkini" bans on the ground of the promotion of "living together". ${ }^{77}$

\subsubsection{Gender equality?}

In media and political debates, gender equality is also invoked as a justification for "burkini" bans. The idea is that the wearing of the "burkini" is not a free choice, but rather imposed by patriarchal culture and/or by men in the wearer's environment. Our interviewees testified that they experience such assumptions as very problematic:

feminism is not about the right to dress as short as possible, but about the right to choose. And it is actually enormously degrading that you just tell women 'look, we are real feminists, and we think that is oppressive'; ${ }^{\prime 8}$

they pretend that all Muslim women are incapable of taking autonomous decisions about their own body, about their own religious experience. There you see superiority and inferiority at work: we will decide for you what is liberating. And all other women are incapable of that. ${ }^{79}$

In September 2016, the Flemish Gender Ombudsperson issued an opinion on "burkini" bans, ruling that such bans cannot be based on gender equality. ${ }^{80}$ She based this opinion largely on the ECtHR judgment in the French face covering case, where the Court rejected the gender equality argument, holding that:

a State Party cannot invoke gender equality in order to ban a practice that is defended by women

- such as the applicant - in the context of the exercise of the rights enshrined in those provisions [Article 8 ECHR on private life and Article 9 ECHR on religious freedom - EB], unless it were to be understood that individuals could be protected on that basis from the exercise of their own fundamental rights and freedoms. ${ }^{81}$

The same reasoning does indeed apply; hence the gender equality argument cannot justify "burkini" bans either.

\subsection{BANNING THE “BURKINI" FOR SPECIFIC REASONS RELATING TO THE SWIMMING POOL CONTEXT?}

We found that in Flemish swimming pools, the reasons that are most frequently invoked to justify a "burkini" ban, or hygiene/ecology, and safety.

\subsubsection{Hygiene and ecology}

\footnotetext{
77 See also Catherine E. Berry, 'The 'Burkini Ban' - A Red Line Even for the European Court of Human Rights?' (Oxford Human Rights Hub, 7 September 2016) ; Joël Andriantsimbazovina in Hervieu (n 7); Charlotte Girard 'Burkini: Entretien croisé des Professeurs Stéphanie Hennette-Vauchez et Joël Andriantsimbazovina sur la decisión du Conseil d’Etat' (2016) 10 La Revue des Droits de l'Homme 1 , 12-13.

${ }^{78}$ Quote from Samira.

${ }^{79}$ Quote from Kareema.

${ }^{80}$ Vlaamse Ombudsdienst, 'Boerkiniverbod gelijkheidsbevorderend?' (20 September 2016.) < www.vlaamseombudsdienst.be/ombs/nl/nieuws/pdf/20160920_boerkiniverbod_gelijkheidsbevorderend.pdf> accessed 22 August 2018.

81 SAS v France (n 17), para. 119.
} 
Swimming pools have to respect strict rules regarding water quality. We found that most dress rules in Flemish swimming pools are motivated by concerns for water quality/hygiene. This is without doubt a legitimate aim that can in principle justify restrictions of fundamental rights in this context. However, there appears to be little ground for the assumption that a "burkini" would cause additional concerns in this regard as compared to a 'regular' female or male bathing suit. UNIA asked the opinion of the Flemish Care and Health Agency (Agentschap Zorg en Gezondheid), a public body, on the argument that wearing a "burkini" in a swimming pool would affect the quality of the water. Its advice ${ }^{82}$ states that it would not be appropriate to ban "burkinis" on grounds of hygiene. It explains that swimwear should be clean, it should be used only for swimming or bathing and should be washed regularly. If used correctly in this manner, "burkinis" comply with hygienic standards for swimwear, according to the Agency. This is not surprising, given that they are made of the same material as other swimwear. The argument that "burkinis" absorb more water because they contain more fabric, is countered as well in the Agency's advice. It states that applicable legislation obliges swimming pools to add minimum 30 litres of fresh water per bather per day, which largely compensates for any additional loss of water that may be created by swimming with a "burkini". The only remaining issue is then the matter of correct use. A "burkini" generally does not have pockets, and is not worn for outdoor recreation, except on a beach. In that sense, it does not present the same hygienic risks as male swimming shorts, which have led many swimming pools to allow only tight "Speedo" models. The need for control on cleanliness of the "burkini" can therefore be regarded as comparable to that of other female swimwear. There may however be a need to verify that a garment is effectively a "burkini" made of lycra or other swimwear fabric. In addition, it may be useful to remind swimmers that they are not allowed to wear underwear under their swimwear. In the latter regard, there is a similarity with some male swimwear. However, a ban on "burkinis" would be a disproportionate measure to counter such risk. A less restrictive measure that would be acceptable though, would be to remind swimmers, for example, those inquiring whether their swimwear is allowed, that underwear has to be removed. All this leads to the conclusion that concerns of hygiene and ecology cannot justify a "burkini" ban. This opinion was shared by the court of first instance of Ghent, with reference to the opinion of the Care and Health Agency. ${ }^{83}$

\subsubsection{Safety}

There can be no doubt that safety concerns merit high priority in a swimming pool context. As a result, they can in principle justify dress restrictions. The European Court of Human Rights recognises a wide margin of appreciation for domestic authorities to decide which measures are necessary to address safety risks. ${ }^{84}$ Yet this presupposes that the safety risk is a real one. In addition, it should still be verified that the restrictive measure is adequate and proportionate in regard to that risk. The Flemish Care and Health Agency reports that it has not received any communication regarding situations of unsafety related to the wearing of a "burkini".$^{85}$ The safety arguments that were collected in this study appeared either speculative or based on misconceptions about the features of a "burkini". It is hard to see how there might be a safety risk for other swimmers or for the wearer. The focus of the safety arguments appears to be on the "skirt" part of the garment, which is in fact not very loose, and no longer than the knee. It seems highly unlikely for instance, that it would cause a risk to the swimmer when she jumps in the water, as some long loose skirts worn as streetwear might. Should there be some model of

\footnotetext{
${ }^{82}$ Advice of Agentschap Zorg en Gezondheid to Interfederaal Centrum voor gelijke kansen en bestrijding van discriminatie en racisme (18 March 2016), in possession of the authors, and quoted in UNIA (n 33).

83 'Ghent case', para 4.8 and 'Merelbeke case', para 4.

${ }^{84}$ See in this regard, with regard to a nurse in a geriatric ward wearing a Christian cross on a chain around her neck: Eweida v UK App nos. 48420/10, 59842/10, 51671/10 and 36516/10 (in the case of Ms Chaplin) (ECtHR, 15 January 2013), paras $96-102$.

85 Ibid.
} 
"burkini" that does pose a safety risk to the wearer in some specific circumstances, it would seem that less restrictive measures than a complete ban would suffice to address it. These could consist for example in regulating the type of "burkini" that can be worn (for example, length of the skirt) or in exonerating the pool management from any responsibility in this regard vis-à-vis the swimmer. In the absence of evidence of any safety risks caused by the wearing of a "burkini", safety concerns cannot justify a "burkini" ban. This reason that was followed by the Court of First Instance of Ghent, stating that neither the municipality of Ghent, nor that of Merelbeke indicates concretely what the alleged safety risk would consist of. ${ }^{86}$

The analysis of ECtHR conformity thus leads to the conclusion that the bans on body covering swimwear that exist in Belgian municipal swimming pools violate the freedom of religion as protected in Article 9 ECHR.

\section{Conclusion}

'In fact, there is no reason why a public authority should determine what a bathing suit should look like', said Catherine, who for many years has been trying in vain to swim with body covering swimwear. An analysis of bans on such swimwear in Flemish municipal swimming pools in the light of the ECHR, reveals that such bans can indeed not be justified. And yet, if it had not been for the commotion at the Côte d'Azur in the summer of 2016, the widespread prevalence of such bans in Belgium would likely have remained under the radar of human rights scholars and activists. Restrictions on Muslim women's religious dress have been the focus of regular public debate and litigation in Belgium since the 1990s. Yet it seems possible that there might be a significant part of the discrimination iceberg that has remained hidden under the water. The widespread prevalence of bans, regardless of actual demand for wearing body covering swimwear, is a striking feature of the findings in this research. Not less striking is the lack of a sound justification for the bans. It is hard to escape the impression that stated reasons for the bans are invented on the spot ('if neutrality does not work, let's invoke hygiene'). It seems that faced with Muslim women's religious dress, banning has become a default option, rather than an exceptional measure that requires sound reasons.

\footnotetext{
${ }^{86}$ Ghent case, para 4.8. and Merelbeke case, para 4.9 (n 52).
} 